\title{
Teaching English as an International Language (EIL) in Nepal
}

\author{
Mohan Singh Saud \\ Tribhuvan University, Nepal
}

Abstract: With the rapid growth and widespread use of English worldwide, there has been a paradigm shift from teaching English as foreign language to teaching English as an international language. However, there hasbeen less discussion on English pedagogy about the global spread of English in this era of globalization, with rapid increase of English speakers around the world. The internationalisation of the status of English, leading to the emergence of World Englishes, has led to discuss the issue of teaching English as an international language (TEIL) to visit the way we conceptualise and teach English. As English is no longer a homogeneous language, English teachers across the world have been teaching English according to their own contexts. Considering this scenario, this article discusses teaching and learning of English as an international language in the context of Nepal, taking Kachru's three concentric circles of English in the global context as the theoretical framework and English as an international language as the conceptual framework, focusing on use of culturally sensitive EIL pedagogy.

Keywords: EFL, EIL pedagogy; Globalization; global English; World Englishes

\section{INTRODUCTION}

With the rapid growth and widespread use of English throughout the world, there has been a paradigm shift from teaching English as foreign language (EFL) to teaching English as an international language (EIL) (Rose \& Montakantiwong, 2018), especially in the contexts of the expanding circle countries (Kachru, 1992). Scholarly discussions on the global spread of English have produced such terms as World Englishes (Kachru, 1985, 1992; Brutt-Griffler, 2002; Jenkins, 2003; Kirkpatrick, 2007), English as an international language (McKay, 2010), and English as a lingua franca (Jenkins, 2000; Seidlhofer, 2005). Issues about the global spread of English have been discussed from a macro-perspective, focusing on the social, economic, and political value of English as a global language (Crystal, 1997), dominance of English over other languages as linguistic imperialism (Phillipson, 1992), and the extinction of minority languages described as language death (Nettle \& Romaine, 2000; Crystal, 2000), or linguistic genocide (SkutnabbKangas, 2000). Despite all these issues, there has been less discussion on English pedagogy about the global spread of English in this era of globalization, with rapid increase of English speakers around the world. The internationalisation of the status of English, leading to the emergence of World Englishes (WE), has led to discuss the issue of teaching English as an international language (TEIL) to visit the way we conceptualise and teach English. As English is no longer a homogeneous language, English teachers across the world have been teaching English according 
to their own contexts. Considering this scenario, this article discusses teaching and learning of English as an international language in the context of Nepal, taking Kachru's (1990) three concentric circles of English in the global context as the theoretical framework, focusing on using culturally sensitive EIL pedagogy (McKay, 2003).

EIL tends to be conceptualized as a perspective (McKay, 2002) or a paradigm ( Sharifian, 2009). Here I will take it as "a paradigm for thinking, research, and practice" (Sharifian 2009, p. 2). "EIL as a paradigm recognises the international functions of English and its use in a variety of cultural and economic arenas by speakers of English from diverse lingua-cultural backgrounds who do not speak each other's mother tongues" (Marlina, 2014). Teaching English as an international language in the multicultural contexts (Sharifian, 2014) is the guiding principle of the EIL paradigm. "Many scholars have claimed that EIL pedagogy is the most suitable pedagogy to the changing sociolinguistic landscape of English and English users" (Zacharias, 2014).

Because of the global spread of English, EIL pedagogy has appeared to be the most widely suggested approach to English pedagogy (McKay, 2003; Matsuda, 2012), in response to the traditional English language teaching which focuses on the monolingual native English speakers (NES) as the norm. As this NES model no longer considers multiple contexts of using English (Zacharias, 2014), EIL pedagogy is the appropriation and it considers the local contexts of the learners valuing 'bilingual English speakers' (McKay, 2003). The traditional EFL approach focuses on native English speakers but the focus of EIL pedagogy is on bilingual English speakers considering the diversity of the local context with various purposes of learning English (Jenkins, 2009; McKay, 2003). In this context, as McKay (2003) argues, an effective EIL pedagogy "must consider the specific goals that lead learners to study English and not assume that these goals necessarily involve attaining full proficiency in the language" (p. 5).

In this article, I will adopt English as an International Language (EIL) as the conceptual framework to introduce the pedagogy of English as an International Language (McKay, 2002, 2003a, 2012). Before this, I will start by discussing the concepts of globalization and global English as the background, and then will go on dealing with World Englishes and English as an international language with special focus on EIL in Nepal.

\section{GLOBALISATION AND GLOBAL ENGLISH}

Global social, cultural, economic and political waves of changes have great impact on the wide use and rapid spread of English in the global sociolinguistic context. As these forces are directly linked to globalization, the status of English also became the issue of discussion in academic literature, particularly from a sociolinguistic perspective. Since its earliest appearance in the 1960s, the term 'globalization' has been used in both popular and academic literature to describe a process, a condition, a system, a force, and an age (Steger, 2003, p.7). By identifying some of the essential qualities of globalization, he offers the following definition:

Globalization refers to a multidimensional set of social processes that create, multiply, stretch, and intensify worldwide social interdependencies 
and exchanges while at the same time fostering in people a growing awareness of deepening connections between the local and the distant (p.13).

Steger indicates that globalization is a multidimensional social process bridging the local and the distant in terms of socio-cultural and economic dynamics. As Steger talks about economic, political, cultural and ideological dimensions of globalization in his book Globalization: A Very Short Introduction (2003), we can define globalization as a social process "characterized by the existence of global economic, political, cultural, linguistic and environmental interconnections and flows that make the many of the currently existing borders and boundaries irrelevant" (Steger, 2003; Schwegler, 2006).

In fact, globalization is a process which integrates world economies, culture, technology and governance. The free movement of goods, services and capital can be taken as the forms of globalization. Globalization is primarily an economic process of interaction and integration associated with social and cultural aspects. As a multifaceted phenomenon, globalization has grown due to the technological advancements in transportation and communication. Now, globalization has become a driving force in almost all sectors including trade, ideology and culture.

Considering the effects of globalization on language in Blommaert's (2010) sense of mobility, there has been a shift from a language as a static system to language as a mobile resource across space and time. Globalization has its great effect on the world's languages. Language is an essential medium which develops the ability to communicate across cultures. Knowledge of one or several languages enables us to think globally and act locally. Languages and globalization are interconnected to one another. Without language (or communication), there would be no globalization, and without globalization, there would be no world languages like English. When economists and linguists write about globalization and its effects on modern societies, what they routinely overlook is the extraordinary nature of language as an economic good. Language can be taken as capital in Bourdieu's sense. It cannot be ignored that language has the economic importance in our current status of globalization. We can easily examine how and why certain languages (e.g., English, Korean, Chinese, Japanese) have acquired great social and economic value, while others (e.g., indigenous languages in Nepal) have become neglected to a marginal status in our socio-cultural context of Nepal.

A language achieves a global status when it develops a special role in every country (Crystal, 2003). There are two main ways for a language to get a global status. Firstly, a language is made the official language of a country, to be used as a medium of communication in such fields as government, courts, media, and the educational system. Such a language is described as a 'second language'. Secondly, a language is adopted in a country's education system without official status. Such as language is described as a 'foreign language'. In both of these ways, English language has enjoyed the special privilege around the world. English now has some kind of special status in the former colonized countries, such as Ghana, Nigeria, India, Singapore, etc. English is now the language taught as a foreign language in over 100 countries, such as Nepal, China, Russia, Spain, Japan and so on. It becomes the language which children are taught when they arrive in school. This 
has created the dichotomy between English as a second language (ESL) and English as a foreign language (EFL) that is different from English as a native language (ENL) spoken by so-called native speakers as mother tongue.

English language achieved dominance over other languages due to economic, technological, and cultural power. Without such a strong power-base, it would not have been used as a global language of communication. In this regard, it would be appropriate to quote Crystal (2003):

Language has no independent existence, living in some sort of mystical space apart from the people who speak it. Language exists only in the brains and mouths and ears and hands and eyes of its users. When they succeed, on the international stage, their language succeeds. When they fail, their language fails. (p.7)

Historically the spread of English around the world was a colonial process. Now due to globalization and power (political and economical), English has become the dominant language in the globalizing world in various sectors such as science, business, communication technology and academia. This is what we call 'English language imperialism' from the approach of Phillipson's (1992) 'linguistic imperialism'. The widespread use of English across the nations has made the whole world 'the global village' in McLuhan's term, and today we are living in this global village as global citizens. As Sharifian (2009) says "For better or worse, by choice or force, English has 'traveled' to many parts of the world and has been used to serve various purposes".

Now many English speakers in the world do not speak English as their first language as the speakers do in America, Britain, Canada, Australia and New Zealand. They often use English as a lingua franca. As a result, this trend has created the notions of native and non-native speakers of English in the traditional sense. Today English is being used globally so much so that there are more bilingual (non-native) speakers of English than there are first language (native) speakers of English (Rai, 2006; McKay, 2012). Global English as a lingua franca is a means of communication between speakers of different mother tongues. Global English is largely a result of economic globalization, transportation, migration and very recent developments in communication technology.

\section{WORLD ENGLISHES AND ENGLISH AS AN INTERNATIONAL LANGUAGE}

Prior to the 1980s, discussions of English worldwide involved on the dichotomy between 'native speaker' and non-native speaker', resulting the labels as English as a Native Language (ENL), English as a Second Language (ESL) and English as a Foreign Language (EFL) (Bolton, 2013). Strevens (1977) identifies ENL, ESL and EFL with English-speaking, English-using and non-English-using countries, respectively (cited in Giri, 2014).

The World Englishes paradigm influenced English studies mostly in the 1980s and early 1990s, challenging the traditional approaches, e.g. the KachruQuirk debate (1990-91), Quirk arguing for Standard English norm whereas Kachru arguing for World Englishes. The scholarly discussion on World Englishes in applied linguistics accepts multiple varieties of English as legitimate and worthy of study (Matsuda, 2003). Consistent with the value applied linguists place on World 
Englishes, English is now taught and learned in many countries as an international language.

The rapid spread of English as a language of communication has stimulated interesting debate about the status of English in its varieties (Kilickaya, 2009), which are commonly called World Englishes (Kachru, 1985). There are several interpretations regarding the meaning(s) of World Englishes (WE). For example, Bolton (2004) in his article World Englishes presents two senses of WE. In the first wider sense, the term functions as an umbrella term covering all varieties of English worldwide such as English as an international language, global English, international English(es), localized varieties of English, new varieties of English, non-native varieties of English, second language varieties of English, world Englishes, new Englishes, including such more traditional terms as ESL (English as a Second Language) and EFL (English as a Foreign Language). In the second narrower sense, the term is used to refer to the 'new Englishes'found in the countries such as Africa and Asia. Elsewhere, Bolton (2013) defines the term 'world Englishes' to refer to "localized forms of English found throughout the world". Jenkins (2006) proposed the term World Englishes to cover new Englishes in Africa and Asia, which are considered as Outer Circle by Kachru. Kachru's (1985) main argument is also on the Outer Circle referring to local indigenized varieties of English in Africa and Asia. However, here I will take the term to cover all Englishes from all circles after Sharifian (2009), thinking that it would be appropriate in the context of Nepal considering English as an international language. Then, Kachru $(1985,1997)$ proposed three concentric circles of World Englishes to divide English-using world, focusing on the historical context of English, the status of the language and the functions in various regions (Kilickaya, 2009). Kachru's three circles include Inner Circle, Outer Circle and Expanding Circle.

In the Kachru's Three-circle Model of World Englishes, the Inner Circle includes the Native English-speaking countries such as Britain, America, Australia, New Zealand and Canada. English is used as a native first language in these countries and the varieties of English used here are said to be the 'norm-providing' varieties in Kachru's term. The Outer Circle includes the former colonial countries such as India, Singapore, Malaysia, Ghana, Kenya, Africa and Nigeria, where English is used as a non-native second language. The English used in these countries is said to be 'norm-developing' varieties in Kachru's term. The Expanding Circle includes countries such as Nepal, China, Japan and Turkey, where English is used as a foreign language as the most useful vehicle of international communication (White, 1997) and where English is becoming an important language in business, science, technology and education (Kilickaya, 2009). The English used in the Expanding Circle is said to be 'norm-dependent' in Kachru's term. Kachru's main concern is on the "Outer Circle in which the institutionalized non-native varieties of English are used in multilingual and multicultural contexts" (Kachru, 1990). The Expanding Circle countries form the largest circle of learning English as a foreign language. Kachru's three concentric circles of WEs: the inner circle, the outer circle and the expanding circle, may be considered as roughly corresponding to ENL, ESL and EFL countries respectively (Giri, 2014). 


\section{WHAT IS ENGLISH AS AN INTERNATIONAL LANGUAGE (EIL)}

English as an International Language (EIL) marks a paradigm shift in TESOL, SLA and the applied linguistics of English, partly in response to the complexities associated with the rapid spread of English around the globe in recent decades (Sharifian, 2009). In fact, it is essential to note that EIL does not refer to any particular variety of English. Agreeing with Sharifian (2009), like Marlina (2014), EIL paradigm "rejects the idea of any particular variety being selected as the medium for international communication". Instead, EIL emphasizes that English, with its pluralized forms, is a language of international and intercultural communication (Sharifian, 2009; Marlina, 2014). EIL as a paradigm recognizes World Englishes, regardless of which 'circles' they belong to (Bolton, 2004; Kachru, 1986, 1992). Here this terminology is used in the wider sense of English referring to all varieties of English used in all circles.

The EIL paradigm also emphasizes the relevance of World Englishes to ELT (Matsuda, 2002). In EIL contexts, English is used between speakers coming from different cultural and national backgrounds (Sharifian, 2009). Canagarajah (2006) maintains that "in a context where we have to constantly shuttle between different varieties [of English] and communities, proficiency becomes complex ... one need s the capacity to negotiate diverse varieties to facilitate communication" (cited in Sharifian, 2009; emphasized by Smith, 2015). As English is the language of international communication, and developing 'intercultural communicative competence' (Byram, 1997) is the norm of teaching and learning English in today's world in contrast to the native speaker-based notion of 'communicative competence' (Hymes, 1972), what Canagarajah argues is quite apt. Alptekin (2002) also argues that with its standardized native speaker norms, the model of communicative competence is utopian, unrealistic, and constraining in relation to English as an International Language (EIL). Considering all these arguments, my argument is also on teaching and learning of English as an international language.

Communication across cultures is an issue which lies at the heart of EIL pedagogy. EIL pedagogy recognizes that English is widely used for intercultural communication at the global level today (Wolf \& Polzenhagen, 2006). Now, it is increasingly argued that intercultural competence, what Sharifian calls 'metacultural competence', needs to be viewed as a core element of 'proficiency' in English when it is used for international communication (Sharifian, 2009, 2013). To elaborate more on this part of discussion, I find it noteworthy to cite Sharifian (2009) once again, a seemingly recognized proponent of EIL:

...most studies of intercultural communication in English have, up until now, focused on NS-NNS intercultural communication. Henceforth, what is needed in the EIL paradigm is an expansion of the scope of speech communities and interlocutors engaged in intercultural communication, especially as most instances of intercultural communication in English today takes place between its non-native speakers. ... in the context of the globalization, or what Sharifian terms 'glocalization' of English, EIL recognizes the fact that the distinction between who is and who is not a native speaker is not 
always clear-cut. The focus in the EIL paradigm is on communication rather than on the speakers' nationality, skin color, and so on...(pp. 4-5)

Thus, in the present context of the global spread of English, claiming that 'English is my native language' is what Holliday (2006) calls 'native-speakerism' as a myth. Kachru (1985) and Widdowson (1994) argue that native speakers cannot claim ownership of English. "The very fact that English is an international language means that no nation can have custody over it" (Widdowson, 1994; cited in Kilickaya, 2009). Thus, the traditional notions of 'native speaker' and 'non-native speaker' of English and the traditional dichotomy between ESL and EFL contexts are becoming blurred, partly because of patterns of migration and mobility, associated with globalization (Bolton, 2013).

\section{TEACHING ENGLISH IN NEPAL AND EIL PEDAGOGY}

Though the use of English in Nepal was first recorded in the seventeenth century (Giri, 2014), English formally entered into Nepal during Ranarchy with the establishment of Durbar School in 1853/54 and it "was a shift to modern system of education from traditional one" (Vir, 1988; cited in Paudel, 2016). In 1918, TriChandra College was established and it started teaching English courses under the supervision of Patana University, India (Bista, 2011). Tribhuvan University, the first university of Nepal, was established in 1959, giving high priority to English in its curriculum. However, after a decade, national wide master plan known as The National Education System Plan (NESP 1971-76) was implemented introducing English language teaching (ELT) formally from school level to the university level of education. This plan is said to have brought a drastic change in the education system of Nepal.

Now, English language teaching has been improved largely in Nepal, with changes in terms of structure of Education, pedagogies and institutions of higher learning (Bista, 2011). Up to now, Nepali is the only official language of Nepal though many private schools, colleges, universities along with some public schools/colleges of the country have adopted English-medium instruction.

Regarding the traditional dichotomy of ESL and EFL, Shrestha (1983) argues that English is not a second language in Nepal because it is not one of the official languages of the country. Rather it is a foreign language because it is taught as a school subject (Shrestha, 1983; Bista, 2011). Kachru's framework of three concentric circles places Nepal under the Expanding Circle (EFL context). However, Giri (2014) argues that English in Nepal is no longer a foreign language because it functions as a lingua franca across various socioeconomic sectors and domains. He identifies English in Nepal as an expanding circle variety, following Kachru's framework, which seems contradictory as there seems no difference between EFL and Expanding Circle contexts except the terminological change. Anyway, I also argue that English in Nepal cannot be taken as EFL, rather it needs to be taken as EIL.

English as an international language (EIL) does not mean a particular variety of English, as mentioned earlier. A number of EIL scholars (Sharifian, 2009; McKay, 2010, 2012; Matsuda, 2012; Strevens ,1992) have suggested that EIL 
should be seen as a continuum between ENL and EFL. Nayar (1997), for example, suggested that the transition from foreign language to second language takes place when the language is used in everyday communication and from second language to native language, when the language is or can be used for all communicative needs and when the wider speech community accepts it (cited in Giri, 2014).

Although communicative language teaching (CLT) has been the dominant approach in ELT, it did not pay adequate attention to local socio-cultural and contextual needs of learning. As a result, the field of ELT moved into a post method era, which emphasizes "a pedagogy of particularity, practicality, and possibility" (Kumaravadivelu, 2003), and EIL pedagogy emerged as a possible response to the global use of English for intercultural communication.

EIL makes use of contextually appropriate and culturally sensitive pedagogy taking into consideration the learners' socio-cultural contexts. This is what Sifakis (2004) calls teaching English as an intercultural language (EIcL). McKay, \& Bokhorst-Heng, 2017) argue for a socially sensitive EIL pedagogy. It is because present-day globalization, migration, and the spread of English have resulted in a great diversity of social and educational contexts in which English learning is taking place.

The use of English internationally includes native speakers as well as the bilingual users of English. Now English is seen as the best medium for communication among people from different language backgrounds. The sociolinguistic realty of the world is that now bilingual English speakers have outnumbered native speakers of English. As Mufwene (2010) has pointed out, "multilingualism has been the norm" in today's global spread of English. McKay (2012) points out that "in Outer Circle countries, their use of English occurs in the context of code-switching and code-mixing. This has an important implications for EIL pedagogy" (p.30). In the context of Nepal, as Giri (2014) has found that codemixing and code-switching, transliteration, and the modification of the standard rules of English in the areas of vocabulary, grammar and writing are common in Nepali variety of English, teaching and learning EIL seems to be the need. This ind icates that Nepal as a norm-dependent country in Kachru's framework is actually wrong. The main purpose of learning English is not to learn the native culture but to develop 'intercultural awareness' (Baker, 2011) for intercultural communication. If so, the label EFL in the context of Nepal seems misleading. Instead, EIL is to be the appropriate label to talk about the teaching and learning of English in Nepal in this globalized age.

The teaching and learning of English takes place in a great variety of contexts (McKay, 2003). Context and culture are the two main elements to be considered in teaching and learning English in the present globalised world. As Nepal is a culturally and linguistically diverse country, 'one-size-fits-all' method of Westerners is not appropriate in our context. A dramatic increase in the number of English speakers, both in outer and expanding circles, and a shift in the culture basis of English have significantly changed the nature of teaching and learning English around the world including Nepal. As English has become the language of technology, education, tourism, translational communication, and academia, the traditional label EFL in the context of Nepal needs terminological change. The 
appropriate term can be then EIL as English is nobody's native language, but everybody's language for international and intercultural communication. Due to this fact, it can be better to say 'bilingual English teachers' rather than 'non-native English teachers' as bi-/multilingualism has become the norm in a multilingual and multicultural country like Nepal.

In Nepal, due to the diversity of local cultures of learning, one method cannot meet the needs of all the learners. Therefore, the bilingual teachers must employ the culturally sensitive methods, recognizing the multilingual and multicultural contexts of English use in their students' learning of English. The growing number of bilingual speakers of English, and the relationship between EIL and the local culture are the important characteristics of English as an international language (EIL) (McKay, 2003). Therefore, an appropriate EIL pedagogy must take ownership of English, selecting teaching content and methods appropriate to the local context. What is appropriate in an international context may not be appropriate in a local context. In this regard, Kramsch and Sullivan (1996) point out that an appropriate pedagogy for the teaching of EIL depends upon local ELT professionals thinking globally but acting locally.

\section{CONCLUSION}

Today English has achieved a status of a global lingua franca because of an increasing growth in the number of English language users and speakers around the world for a wider variety of purposes. Teaching English as an International Language (TEIL) is teaching English as a truly pluricentric language (Sharifian, 2014), which focuses on culturally sensitive and contextually appropriate use of English. The traditional approach in ELT aimed at developing 'linguistic competence' (Chomsky, 1965), and in more recent decades 'communicative competence' (Hymes, 1972), which was based on the native speakers' competence of homogeneous speech communities of language. The TEIL approach acknowledges the varieties of English in the rapid globalizing world, focusing on the development of intercultural communication skills for successful communication between speakers from various language and cultural backgrounds in the global contexts, keeping diversity in its heart. EIL pedagogy recognizes and legitimizes the value of bilingual teachers of English with ownership of it. Thus, a label that divides people as native or non-native speakers of English is considered to be a traditional construct "for understanding the linguistic creativity in multilingual situations across cultures" (Kachru, 1985) and "for expanding understandings of what it means today to be a competent teacher of English" (McKay, 2012).

Since the majority of English speakers are bilingual in today's global context, an EIL pedagogy needs to be culturally sensitive and socially responsible that promotes multilingualism and multiculturalism, developing intercultural awareness in the learners for successful intercultural communication. An appropriate EIL pedagogy needs to resonate with the local linguistic landscape in multicultural contexts. Only the EIL pedagogy can make use of cultural and linguistic diversity of the learners as a valuable resource for teaching and learning English. Given this situation, I propose for replacing the traditional so-called EFL terminology by EIL in the context of Nepal, and suggest for the socially sensitive 
EIL pedagogy, supporting McKay (2003; 2012). I also argue for the 'English speaking world' rather than 'English speaking countries' as English has become a global language today.

\section{REFERENCES}

Alptekin, C. (2002). Towards intercultural communicative competence in ELT. ELT journal, 56(1), 57-64.

Baker, W. (2011). Intercultural awareness: Modelling an understanding of cultures in intercultural communication through English as a lingua franca. Language and Intercultural Communication, 11(3), 197-214.

Bista, K. (2011). Teaching English as a foreign/second language in Nepal: Past and present. Online Submission, 11(32), 1-9.

Blommaert, J. (2010). The sociolinguistics of globalization. Cambridge: Cambridge University Press.

Bolton, K. (2004). World Englishes. In A. Davies \& C. Elder (Eds.), The handbook of applied linguistics (pp. 367-396). Oxford, UK: Blackwell Publishing.

Bolton, K. (2013). World Englishes, globalization, and language worlds. In N.L. Johannesson, G. Melchers, \& B. Björkman (Eds.), Of butterflies and birds, of dialects and genres, (pp. 227-251). Stockholm University.

Byram, M. (1997). Teaching and assessing intercultural communicative competence. Multilingual Matters.

Crystal, D. (2000). Language death. Cambridge: Cambridge University Press.

Crystal, D. (2003). English as a global language. Cambridge University Press.

Giri, R. A. (2014). Changing faces of English: Why English is not a foreign language in Nepal. Journal of World Languages, 1(3), 192-209.

Holliday, A. (2006). Native-speakerism. ELT journal, 60(4), 385-387.

Hymes, D. (1972). On communicative competence. Retrieved from http://smjegupr.net/wp-content/uploads/2012/05/ESPA-3246-OnCommunicative-Competence-p-53-73.pdf

Jenkins, J. (2006). Current perspectives on teaching world Englishes and English as a lingua franca. TESOL Quarterly,40(1), 157-181.

Jenkins, J. (2009). Exploring attitudes towards English as a lingua franca in the East Asian context. In K. Murata \& J. Jenkins (Eds.), Global Englishes in Asian contexts: Current and future debates (pp. 40-59). New York: Palgrave.

Matsuda, A. (2012). Teaching materials in EIL. In L. Alsagoff., S. L. McKay., G. Hu., \& W.A. Renandya (Eds.), Principles and practices for teaching English as an International Language (pp. 168-185). New York: Routledge.

Kachru, B. (1992). World Englishes: approaches, issues and resources. Language Teaching, 25, 1-14. Cambridge University Press. 
Kachru, B. B. (1985). Standards, codification and sociolinguistic realism: the English language in the outer circle. In R. Quirk and H.G. Widdowson (Eds.), English in the world: Teaching and learning the language and literatures (pp.11-30). Cambridge: Cambridge University Press.

Kachru, B. B. (1990). World Englishes and applied linguistics. World Englishes, 9(1), 3-20.

Kachru, B.B. (1986). The Alchemy of English: The Spread Functions and Models of Non-Native Englishes. Oxford: Pergamon.

Kachru, B.B. (Ed.). (1992). The other tongue: English across cultures. (2nd ed.). Urbana and Chicago: University of Illinois Press.

Kilickaya, F. (2009). World Englishes, English as an international language and applied linguistics. English Language Teaching, 2(3), 35.

Kirkpatrick, A. (2007). World Englishes: Implications for international communication and English language teaching. Cambridge: Cambridge University Press.

Kramsch, C., and Sullivan, P. (1996). Appropriate ped agogy. ELT Journal, 50. 199212.

Kumaravadivelu, B. (2003). Beyond methods: Macrostrategies for language teaching. Yale University Press.

Marlina, R. (2014). The pedagogy of English as an international language (EIL): More reflections and dialogues. In R. Marlina, \& R.A. Giri (Eds.), The pedagogy of English as an international language: Perspectives from scholars, teachers, and students (pp. 1-19), (Vol. 1). Springer.

Matsuda, A. (2002). International understanding through teaching world Englishes. World Englishes, 21 (3), 436-440.

Matsuda, A. (2003). Incorporating world Englishes in teaching English as an international language. TESOL Quarterly, 37(4), 719-729.

Matsuda, A. (2012). Principles and practices of teaching English as an international language. Bristol: Multilingual Matters.

McKay, S. L. (2002). Teaching English as an international language: Rethinking goals and perspectives. New York: Oxford University Press.

McKay, S. L. (2003a). Toward an appropriate EIL pedagogy: Re-examining common ELT assumptions. International journal of applied linguistics, 13(1), 1-22.

McKay, S. L. (2003b). Teaching English as an international language: The Chilean context. ELT journal, 57(2), 139-148.

McKay, S. L. ( 2010). English as an international language. In N. Hornberger and S. L. McKay (Eds.), Sociolinguistics and language education, (pp. 89115). Bristol: Multilingual Matters.

McKay, S.L. (2012). Principles of teaching English as an international language. In L. Alsagoff, S. L. McKay, G. Hu, \& W. A. Renandya (Eds.), Principles 
and practices for teaching English as an international language, (pp. 2846). New York: Routledge.

McKay, S. L., \& Bokhorst-Heng, W. D. (2017). International English in its sociolinguistic contexts: Towards a socially sensitive EIL pedagogy. Routledge.

Mufwene, S. S. (2010). Globalization, global English, and world English (es): Myths and facts. In N. Coupland (Ed.), The handbook of language and globalization, (pp.31-55). Chichester: Wiley-Blackwell.

Nayar, P. B. (1997). ESL/EFL dichotomy today: Language politics or pragmatics?. TESOL Quarterly, 31(1), 9-37.

Nettle, D., \& Romaine, S. (2000). Vanishing voices: The extinction of the world's languages. Oxford: Oxford University Press.

Noam, C. (1965). Aspects of the theory of syntax. Cambridge, Massachusetts: MIT Press.

Paudel, T. (2016, January). English in Nepal: From colonial legacy to professionalism. ELT Chautari. Retrieved from http://eltchoutari.com/2016/01/english-in-nepal-from-colonial-legacy-toprofessionalism/

Phillipson, R. (1992). Linguistic imperialism. Oxford: Oxford University Press.

Rai, V. S. (2006). English, Hinglish and Nengliah. Journal of NELTA, 11 (1), 3439.

Rose, H., \& Montakantiwong, A. (2018). A tale of twoteachers: A duoethnography of the realistic and idealistic successes and failures of teaching English as an international language. RELC Journal, 49(1), 88-101.

Schwegler, A. (2006). Syllabus: Language and globalization. Irvine: University of California.

Seidlhofer, B. (2005). English as a lingua franca. ELT journal, 59(4), 339-341.

Sharifian, F. (2009). Cultural conceptualizations in English as an international language. In F. Sharifian (Ed.), English as an international language, (pp. 242-253). Brostol: Multilingual Matters.

Sharifian, F. (2009). English as an international language: An overview. In F. Sharifian (Ed.), English as an international language, (pp. 1-18). Brostol: Multilingual Matters.

Sharifian, F. (2013). Globalisation and developing metacultural competence in learning English as an International Language. Multilingual Education, 3(1), 7.

Sharifian, F. (2014). Teaching English as an International Language in Multicultural Contexts: Focus on Australia. In R. Marlina, \& R.A. Giri (Eds.), The pedagogy of English as an international language: Perspectives from scholars, teachers, and students (pp. 35-46), (Vol. 1). Springer. 
Sharifian, F. (Ed.). (2009). English as an international language: Perspectives and pedagogical issues. Bristol: Multilingual Matters.

Shrestha, R. (1983). English as a second language/English as a foreign language distinction: Its pedagogy and the Nepalese context. Contributions to Nepalese Studies, 11(1), 45- 59.

Sifakis, N. C. (2004). Teaching EIL-Teaching international or intercultural English? What teachers should know. System, 32(2), 237-250.

Skutnabb-Kangas, T. (2000). Linguistic genocide in education - Or worldwide diversity and human rights?. Mahwah, NJ: Lawrence Erlbaum Associates, Inc., Publishers.

Smith, J. (2015). English as an International Language (EIL), world Englishes within an international context, and the tower of Babel. Retrieved from https://files.eric.ed.gov/fulltext/ED554546.pdf

Steger, M.B. (2003). Globalization: A very short introduction. Oxford: Oxford University Press.

Strevens, P. (1992). English as an international language: Directions in the 1990s. In B. B. Kachru (Ed.), The other tongue: English cross cultures, (pp.2747). Urbana: University of Illinois Press.

White, R. (1997, December). Going round in circles: English as an international language and crosscultural capability. In Cross-cultural Capability Conference (Vol. 97).

Wolf, H. G., \& Polzenhagen, F. (2006). Intercultural communication in English: Arguments for a cognitive approach to intercultural pragmatics. Intercultural Pragmatics, 3(3), 285-321.

Zacharias, N. T. (2014). Integrating EIL pedagogy in a pre-service teacher education program. TEFLIN Journal, 25(2), 217-232. 